\title{
Foundation and Perspectives of the Use of Plant Extracts as Performance Enhancers in Broilers
}

\section{Author(s)}

Rizzo PV

Menten JFM

Racanicci AMC

Santarosa J

Universidade de São Paulo

Escola Superior de Agricultura "Luiz de

Queiroz"- ESALQ

\section{Mail Address}

Prof. Dr. José Fernando Machado Menten Departamento de Zootecnia

Escola Superior de Agricultura "Luiz de Queiroz" - ESALQ

Avenida Pádua Dias, n 11

Caixa Postal: 9

13418-900. Piracicaba, São Paulo, Brasil.

E-mail: jfmmente@esalq.usp.br

\section{Keywords}

Broilers, performance, plant extracts.

Research study funded by Fundação de Amparo à Pesquisa do Estado de São Paulo (FAPESP).

\section{ABSTRACT}

Feed is responsible for about $70 \%$ of broilers production costs, leading to an increasing number of studies on alternative dietary products that benefit bird performance and lower production costs.

Since the 1950s, antimicrobial additives are the most frequently used performance enhancers in animal production and their positive results are observed even in high-challenge conditions. Since the 1990s, due to the ban of the use of some antibiotics as growth promoters and the growing trend of the public to consume natural products, plant extracts have been researched as alternatives to antibiotic growth promoters.

The first study that evaluated the antibacterial activities of plant extracts was carried out in 1881; however, they started to be used as flavor enhancers only during the next decades. With the emergence of antibiotics in the 1950s, the use of plant extracts as antimicrobial agents almost disappeared.

There are several studies in literature assessing the use of plant extracts, individually or in combination, as antimicrobials, antioxidants, or digestibility enhancers in animal feeds. Research results on the factors affecting their action, such as plant variety, harvest time, processing, extraction, as well as the technology employed to manufacture the commercial product and dietary inclusion levels show controversial results, warranting the need of further research and standardization for the effective use of plant extracts as performance enhancers, when added to animal feeds.

This article aims at presenting plant extracts as alternatives to antibiotics, explaining their main modes of action as performance enhancers in broiler production.

\section{INTRODUCTION}

Brazil is the largest exporter and the third largest producer of chicken meat in the world, leading to considerable interest and significant investments in the poultry industry. Data of the 2006 annual report of the Brazilian Association of Broiler Producers and Exporters (ABEF) show that chicken meat ranks third among the agribusiness export product, and the sixth Brazilian product in exports. During that year, more than 9.3 million tons of chicken meat were produced, with 2.7 million tons exported. The domestic market is also promising, with a consumption of $35.68 \mathrm{~kg}$ chicken meat per capita per year, which represents an increase of more than $60 \%$ in the last 10 years (ABEF, 2008).

Brazilian competitiveness in the global meat market is maintained by genetic improvement, management, health control and nutrition, allowing excellent live performance. One of the most important factors is nutrition, as it represents more than $70 \%$ of production costs, and therefore is subject of many scientific studies. Researchers are constantly 
Rizzo PV, Menten JFM, Racanicci AMC, Santarosa J seeking alternatives to reduce feed costs and to improve animal performance, as well as to satisfy consumers, who increasingly demand safe food products.

Antimicrobial additives are the performance enhancers most frequently used in animal production since the 1950s (Menten, 2001), allowing higher weight gain and better feed conversion ratio in animals reared under intensive conditions. In the last few years, one of the main concerns of the poultry industry is the ban of antibiotic growth promoters by the European Union. These products are now considered as human health risk factors for their possible role in the emergence of microbial resistance (Brugalli, 2003).

There are few scientific studies on the use of plants or their secondary metabolites for therapeutic, prophylactic, or performance-enhancing purposes in animals. However, the recent restrictions to the use of antibiotic growth promoters have stimulated the search for alternative additives. In this sense, the importance of the possibility of exploring the antimicrobial potential - as well as other properties of plants and their respective compounds (Scheuermann \& Cunha Junior, 2005).

\section{PERFORMANCE ENHANCERS}

\section{Definition}

Performance enhancers - until recently called growth promoters - are organic synthetic compounds, chemical compounds, or simple inorganic elements used to improve animal growth rate and/or feed conversion ratio. Antibiotics and chemotherapeutic drugs are the most frequently used performance enhancers in animal production and have been successfully used in poultry production, particularly under field conditions with high health challenge (Brugalli, 2003).

The antibiotic concept appeared in 1877 when Pasteur and Joubert observed that Bacillus anthracis quickly multiplied in sterilized urine, but did not survive when a common air bacterium was simultaneously added to the urine. This finding was the origin of the concept of antibiosis, an association where an organism harms the growth of another organism (Andrade, 2007).

Antibiotics are presently defined as natural metabolites of fungi, bacteria, or yeast that inhibit bacterial proliferation by direct action, bactericidal effect, or bacteriostatic effect on sensitive bacteria and/or fungi. These effects may be due to interference in cell wall synthesis, changes in the permeability of
Foundation and Perspectives of the Use of Plant Extracts as Performance Enhancers in Broilers

the cytoplasmic membrane, interference in chromosome replication, and interference in cell protein synthesis (Mellor, 2000).

\section{Background}

In ancient times, fungi were used by the Chinese, Egyptian, and Greek to cure infections, but their mode of action was not known.

Modern research on antibiotics started in 1928 in England, when Alexander Fleming discovered penicillin. After many years of study, Ernst Chain and Howard Florey were able to produce and to purify this antibiotic. The second half of the 20th century was the most prolific for human and animal medicine in terms of new technologies applied to antibiotics.

By the end of the Second World War, large-scale food production was necessary, and extensive animal production was no longer able to supply the increasing demand for food. Animals then started to be intensively raised, and antibiotics started to be added to the feeds as growth promoters. Several studies carried out at that time proved the positive results in growth and productivity of the animals reared with the continuous use of dietary antibiotics (NRC, 1999), allowing better production efficiency, despite the intensive conditions of rearing.

The study conducted by Coates et al. (1963) showed that antibiotics did not promote the growth of broilers raised in a germ-free environment as compared to those raised in a conventional environment, leading the authors to conclude that antibiotics suppressed the growth of some microorganisms responsible for growth depression.

A highly competitive industry developed creating products (antibiotics and chemotherapeutics) very efficient as growth promoters and increasingly specific against Gram-negative and Gram-positive bacteria.

Some years after the approval of the first antibiotics for the use in animal diets as growth promotes by the Food and Drug Administration - FDA, some concerns as to their effect on human health aroused. Initially, these concerns were linked to antibiotic residues in meat and their potential risks of causing resistance in human pathogens. Later, the possible resistance to antibiotics developed by bacteria that may survive after being exposed to the drug in the animal was the focus of attention (NRC, 1999).

In the 1960s, the Swann Report was published in the UK, recommending that only antibiotics that had little or no applications as therapeutic agents in humans and animals and did not interfere with the drugs 
prescribed for therapeutics inducing the development of more resistant strains should be used as growth promoters (Andrade, 2007).

The phasing out of the use of antibiotic growth promoters in animal feeds started in the European Union in 1994, and as of January 1st, 2006, antibiotics as performance enhancers in animal feeds were completely banned.

In Brazil, the compounds used as performance enhancers follow the regulations of the Ministry of Agriculture and the Codex Alimentarius. These regulations establish that the use of antibiotics in animal feeds should not exceed maximum residue limits (MRL), which is the amount of a chemical substance allowed to be present in $1 \mathrm{~kg}$ of feed and that, if ingested by an individual during its entire live, does not cause undesirable or toxic effects (Aveworld, 2005).

\section{Mode of action}

There are no conclusive results proving that dietary antimicrobials cause a reduction in total microorganism counts in the digestive tract; however, there are evidences that they are capable of selecting microorganisms adapted to the modified environment.

Changes in the microbiota would benefit animals by different mechanisms: nutrient sparing, control of clinical diseases, protective effect against the production of toxins in the gastrointestinal tract, and metabolic effects (Menten, 1995; Mellor, 2000). It is believed that the simultaneous action of some of these mechanisms generate the performance benefits observed in broilers and other domestic animals (Menten, 1995).

\section{Antibiotic performance enhancers in animal production}

Antibiotics can be used preventively, therapeutically, or as performance enhancers, promoting positive effects on animal production. During the last decades, several studies (Coates et al., 1963; Visek, 1978; Thomke \& Elwinger, 1998a; Thomke \& Elwinger, 1998b) confirmed the performance enhancer effect of antibiotics added in subtherapeutic doses to animal feeds.

However, issues such as loss of antibiotic efficiency along time and risk of residues in food of animal origin, with the possible development of bacterial resistance in humans, have concerned consumers (Thomke \& Elwinger, 1998b), creating a significant problem for poultry production.

Bacterial resistance may occur naturally when bacteria are not sensitive to antibiotics, or be acquired, when sensitive bacteria become resistant to antibiotics. This resistance may be caused by loss of membrane permeability, active exclusion of the antimicrobial compound, changes in the binding sites, changes in the membrane receptor, overproduction of target enzymes, alternative metabolic pathways, mutations, genetic transference or efflux (Aveworld, 2005).

Another cause of bacterial resistance is the reduction of the number of antibiotics used in shuttle programs due to the ban of the use of some antibiotics in animal feeds. In addition, in the last few years, few new antibiotics have been discovered (Cowan, 1999). The lack of available options for shuttle programs caused the rapid loss of efficacy of some of those antibiotics (Aveworld, 2005).

\section{Plant extracts}

\section{Definition}

Plant extracts are derived from plant products, individually or in combinations used as spices and flavoring agents in foods. These plant products may be classified as herbs or spices. Herbs are the dried leaves of aromatic plants, usually found without stems, whereas spices are the dry parts of the plants, except for the leaves (Peter, 2001).

\section{Background}

Plant extracts are important components of traditional medicine, and its use follows the history of mankind, not only in disease treatment, but also in cooking, religious rituals, and even in mummification processes.

Records with more than 4,000 years make references to plants, such as the poppy (Papaver somniferum), whose alkaloids were used as narcotics, and belladonna (Atropa belladonna), whose liquid extract was used to dilate pupils (then considered a feminine beauty mark) and to produce poisons. Morphine, derived from opium extracted from poppies, is currently used as a narcotic, whereas atropine and scopolamine, both extracted from belladonna, are used in ophthalmics and also as antispasmodic agent (Carvalho, 2005).

The records on studies with plant extracts date from only 2,000 years ago, when essential oils were obtained by distillation. After the 13th century A.D., essential oils started to be manufactured by chemists, and their pharmacological effects, described in pharmacopoeias. However, their use was only disseminated in London, 
and consequently to the rest of Europe, in the $14^{\text {th }}$ century (Burt, 2004).

In 1881, De La Croix carried out the first study on the antibacterial properties of plant extracts (Boyle apud Burt, 2004), and the use of essential oils to provide flavor to foods was disseminated in the following decades. In 1945, with the development of the synthetic pharmaceutical chemistry and the emergence of antibiotics produced by bacterial fermentation, there was a marked decrease in the research of medicinal plants (Scheuermann \& Cunha Junior, 2005), and the use of plant extracts as antimicrobials almost disappeared (Cowan, 1999).

In the 1990s, due to ban of the use of some antibiotics as growth promoters, and the increasing public trend to consume natural products, plant extracts re-emerged as alternatives for the replacement of antibiotics in alternative therapeutics.

\section{The use of plant extracts}

In the last few years, the consumer trend of seeking for natural and high-quality products led to the development of research involving chemical and pharmacological studies of medicinal plant, aiming at obtaining new products with therapeutic properties (Cechinel Filho, 1998). The number of studies on the use of plant extracts in animal feeding also significantly increased in Europe in the search of alternatives to antibiotics as performance enhancers. In Brazil, however, this subject has been only recently called the attention of researchers, and consequently only few studies have been carried out.

Plant extracts are typically used in animal feeds in the form of oil-resin or essential oils. Oil-resin is obtained by percolation, with the use of solvents, and results in a liquid or paste consisting of resin and chemical and organic substances, which confer specific color and viscosity to the extract. An essential oil is a homogenous liquid consisting of several chemical substances, and it is obtained by steam distillation. Essential oils are the most frequently used in animal diets.

Essential oil analyses show that they consist mainly of terpenes, which are present as hemiterpenes, monoterpenes, or sesquiterpenes and their derivatives (Trombetta et al., 2005). In addition, oxygenated components (alcohols, esters, aldehydes, ketones, etc.) may be present, as well as small amounts of non-volatile residues (paraffin, wax, etc.) (Losa, 2001). Essential oils may also contain phenolic products, classified as phenylpropanoids (Peres, 2007). According to Langhout (2005), more than 2600 different components present in essential oils have been identified, and part has been synthetically produced.

The part of the plant from where the essential oil is derived depends on the plant species. For instance, in plants of the family Lamiaceae, essential oils occur in the glandular trichomes, whereas in plants of the family Apiaceae, they are stored in the oil channels. Essential oils may also be stored in the leaves (lemon grass, eucalyptus, laurel), flowers (orange tree), bark or stem (cinnamon), fruits (anise), and other parts of the plants.

The components of the essential oils are produced by the plant secondary metabolism. This means that they are not always required by the plant life cycle, but they play important roles in the interaction of the plant with the environment, such as defending the plant against the attack of pathogens, attracting beneficial organisms, and protecting against abiotic stresses, i.e., those associated with temperature changes, soil water content, exposure to ultraviolet rays, and mineral nutrient deficiencies (Peres, 2007). Therefore, the composition and concentration of secondary metabolites in a plant may vary according plant species, weather changes during plant development, plant origin, harvest time, type of material (fresh or dried) (Janssen et al., 1987; Cechinel Filho, 1998), extraction/distillation method and storage conditions and period (Huyghebaert, 2003; Janssen et al., 1987).

According to Kamel (2000), the positive effects of plant extracts on animal nutrition are associated to the composition of its active principles and secondary components. Active principles are chemical components present in the entire plant or in specific parts that confer some therapeutic activity to medicinal plants (Martins et al., 2000).

The substance that constitutes the active principle of an essential oil may be found in different plants, and often in different concentrations. Thymol, for instance, despite being found in the essential oils of thyme (41\%) and oregano (10\%) (Kamel, 2000), can only be considered an active principle in thyme, where as in oregano, the active principle is carvacrol, which is present in $60 \%$ of this plant essential oil.

The presence of several active principles in plant extracts is explained by the fact that the plants develop several metabolites with complementary functions in the defense against pests and diseases (Peres, 2007). Although a plant may contain hundreds of secondary metabolites, only those present in higher concentrations are usually isolated and studied (Cechinel Filho, 1998). 
Rizzo PV, Menten JFM, Racanicci AMC, Santarosa J
Plant extracts present some advantage as compared to traditional antimicrobials because the latter have a single active principle. Therefore, the presence of several compounds in one product may have a synergistic beneficial effect (Peres, 2007) in the improvement of animal performance. When added to animal diets, the active principles of plant extracts are absorbed in the intestine by the enterocytes and quickly metabolized by the body. The products of this metabolism are transformed in polar compounds by conjugation with glucuronate, and excreted in the urine. Other active principles can be eliminated during respiration as $\mathrm{CO}_{2}$. The rapid metabolization and short half-life of active principles suggests that the risk of accumulation of these compounds in the tissue is negligible (Kohlert et al., 2000).

Species such as Hypericum perforatum (St. John's wort), Allium sativum (garlic), Origanum majorana (marjoram), Origanum vulgare (oregano), Mentha piperita (peppermint), Rosmarinus officinalis (rosemary), Thymus vulgaris (thyme), Juniperus communis (juniper), Capsicum annuum (chili pepper) and Allium cepa (onion) called the attention of animal nutrition researchers, as the active principles of these plants may be beneficial for animals (Kamel, 2000). Considering the wide variety of existing plants, the biggest challenge in the use of plant extracts as alternative to the use of antibiotics is the identification and measurement of the effects of the different components present in essential oils on the animal.

\section{MODE OF ACTION OF PLANT EXTRACTS}

\section{Antimicrobial activity}

Antimicrobial activity is one of the intrinsic effect of plant extracts, as several studies published in scientific literature show clear evidence of in vitro antimicrobial, antifungal, and antiviral activities of plant extracts against pathogens that attack animals (Mitsch et al., 2004; Santúrio et al., 2007), food (Juven et al., 1994; Helander et al., 1998), and humans (Didry et al., 1994).

The essential oils of laurel, cinnamon, thyme, and clove (Smith-Palmer et al., 1998) as well as of oregano, basil, coriander, and other plants (Elgayyar et al., 2001) were tested against bacteria and fungi present in foods, and the results demonstrated the important antimicrobial potential of oregano essential oil, even against Gram-negative bacteria, which are typically very resistant to the action of essential oils. According to Smith-Palmer et al. (1998), the essential oils of oregano, cinnamon, and thyme are able to maintain
Foundation and Perspectives of the Use of Plant Extracts as Performance Enhancers in Broilers

the same bacteriostatic capacity at $4-35^{\circ} \mathrm{C}$ against Listeria monocytogenes, a Gram-positive bacterium whose control is of utmost importance for the food industry. However, when tested against different Salmonella serovars of poultry origin (Santúrio et al., 2007), only oregano essential oil presented high activity, causing bacterial death in $50 \%$ of the studied serovars, whereas thyme and cinnamon essential oils presented moderate activities. It must be noted that the results of the in vitro antimicrobial activity of a essential oil may vary as a function of the methodology used for its determination, and therefore further in vivo trials are warranted to validate the results obtained (Hammer et al., 1999).

The antimicrobial action of oregano essential oil against Salmonella spp. was also observed by Peñalver et al. (2005) in a study with intestinal bacteria of poultry and swine. That essential oil presented minimum inhibitory concentration of $0.25-1 \%$ for Salmonella ( $S$. enteritidis and S.essen in poultry, and $S$. choleraesuis and S. typhimurium in swine) and of $4 \%$ for Escherichia coli poultry and Escherichia coli ETEC. Minimum inhibitory concentration (MIC) is used to evaluate the antimicrobial activity of a product and its has different definitions in literature (Burt, 2004). In the above study, MIC was defined as the lowest concentration that is capable of inhibiting the visible growth of the studied microorganism in an agar plate.

In practice, plant extracts should be included in feeds at much higher doses to produce the same bactericidal or bacteriostatic effect observed in vitro. Therefore, in vivo, the mode and site of action of the active components of essential oils depend on their structure, metabolism, and inclusion level (Brugalli, 2003). This stresses the need to carry out detailed studies of plant extracts to be added to animal diets.

The combination of active principles of some plant extracts apparently affects Clostridium perfringens proliferation in the intestine of broilers. A significant reduction of $C$. perfringens colonization was observed in the intestine of broilers fed diets containing mixtures of thymol, eugenol, curcumin and piperin, or thymol, carvacrol, eugenol, curcumin and piperin (Mitsch et al., 2004). The in vitro effects of essential oils and the effects of digestive enzyme stimulation, intestinal flora stabilization, and inactivation of $C$. perfringens toxins may favor a reduction of clostridium colonization in the intestines. This fact stresses the importance of conducting studies to evaluate performance parameters of poultry fed plant extracts, as necrotic enteritis - disease caused by C. perfringens - damages 
the intestinal mucosa, which results in lower feed intake, mortality, and consequently, worse performance.

Most essential oils exert their antimicrobial effect by damaging the bacterial cell wall, denaturating and coagulating proteins. They change the permeability of the cytoplasmic membrane to hydrogen $\left(\mathrm{H}^{+}\right)$and potassium $\left(\mathrm{K}^{+}\right)$ions, causing the interruption of essential cell processes, such as electron transport, protein translocation, phosphorylation steps and other enzymedependent reactions, resulting in loss of chemiosmotic control of the affected cell, leading to cell death (Dorman \& Deans, 2000).

Changes in the permeability of cell wall membrane of bacteria are due to the lipophilic characteristic of essential oils, which accumulate in the membrane. The external membrane of Gram-negative bacteria contains lipopolysaccharides, forming a hydrophilic surface. This hydrophilia creates a barrier to the permeability of hydrophobic substances, such as essential oils (Dorman \& Deans, 2000). This explains the resistance frequently observed in Gram-negative bacteria to the antimicrobial effect of some essential oils (Chao et al., 2000).

It is thought that the changes in membrane permeability may not be the direct cause of bacterial cell death, as the studies conducted by Trombetta et al. (2005) revealed that monoterpenes can cross the lipid bilayer, penetrate the cell, and interact in specific sites, exerting their antimicrobial activity intracellularly.

Plant extract antimicrobial activity results obtained in in vitro experiments, together with the reemergence of the interest in natural therapeutics and food safety concerns, demand further studies to demonstrate the efficacy of plant extracts in improving animal performance.

\section{Antioxidant activity}

The antioxidant activity of plant extracts is mainly related to the presence of phenolic compounds. However, compounds such as flavonoids (present in oregano and thyme) and terpenoids (e.g., thymol, carvacrol, and eugenol) also present antioxidant activity. This substance may intercept and neutralize free radicals, preventing the propagation of the oxidation process (Hui, 1996).

Rosemary (Rosmarinus officinalis L.) and sage (Salvia officinalis L.) are the herbs with the highest antioxidant potential (Madsen et al., 1997), and its protective effect on meats was demonstrated. Other plant extracts, such as Cretan dittany (Origanum dictamnus), cultivated in
Greece, and mate (Ilex paraguariensis), a well-know Brazilian herb also cultivated in Uruguay, Paraguay, and Argentina, also show antioxidant potential when added as ground dried extract to chicken meat (Racanicci et al., 2004; Racanicci et al., 2008).

Some essential oils, such those of clove, thyme, and sage, despite presenting antioxidant action, should not be added in large amounts to foods, as they may negatively affect food flavor and aroma (Madsen et al., 1997)

Aiming at solving these problems, recent research studies have assessed if this same antioxidant effect can be obtained by the supplementation of plant extracts or essential oils in animal feeds, as the use of synthetic antioxidants in animal nutrition is restricted (Valenzuela et al., 2003).

Recent studies show that the addition of oregano essential oil to broiler feeds improved the oxidative stability of chicken meat (Botsoglou et al., 2002a; Botsoglou et al., 2002b; Botsoglou et al., 2003a), turkey meat (Botsoglou et al., 2003b) and rabbit (Botsoglou et al., 2004).

According to Lopez-Bote et al. (1998), the supplementation of sage and rosemary oil-resin in broiler diets increased the oxidative stability of thighs and breast meat. In addition, Luna et al. (2007) showed that thymol and carvacrol, present in oregano essential oil, were able to replace synthetic antioxidants in broiler diets, promoting similar protection against lipid peroxidation of breast meat samples, probably because this meat has low fat content.

Therefore, it is suggested that plant extracts, when directly added to feeds, may influence the oxidative stability of meat after slaughter.

\section{Effects of plant extracts on digestibility}

During the digestive process, the presence of enzymes is essential for the digestion of nutrients. It is believed that some plant extracts may stimulate the production of saliva, and of gastric and pancreatic juices, favoring the secretion of enzymes, and improving nutrient digestibility (Mellor, 2000).

Aromatic compounds, such as capsaicin, active principle of the chili pepper (Capsicum annum), have shown efficient stimulation of pancreatic and intestinal enzymes in monogastric animals. Consequently, they promote a reduction of the intestinal viscosity, making the digestive process more efficient (Brugalli, 2003).

In addition to capsacine, other plant active components, such as eugenol and cinnamaldehyde, active principles of clove and cinnamon, respectively, 


\section{Rizzo PV, Menten JFM,} Racanicci AMC, Santarosa J also have digestion-stimulating properties (Kamel, 2000).

Different mixtures of plant extracts have shown positive effects on animal diet digestibility. The inclusion of graded levels of a mixture containing clove, thyme, and oregano essential oils, with the active principles eugenol and carvacrol in newly-weaned piglet diets increased apparent dry matter digestibility as compared with diets with or with no addition of antibiotic (Oetting et al., 2006). García et al. (2007) observed that finisher broiler diets supplemented with a mixture of sage, thyme, and rosemary or with a commercial product containing capsaicin, cinnamaldehyde, and carvacrol present similar ileal dry matter and protein digestibilities as the diet supplemented with antibiotic, and significantly higher than the control diet.

When evaluating the same mixture of plant extracts in the grower and finisher broiler diets, Hernández et al. (2004) demonstrated that the grower diet presented better dry matter digestibility when the mixture containing sage, thyme, and rosemary plant extracts was added. As to crude protein digestibility, the diets containing antibiotic or a commercial product with capsaicin, cinnamaldehyde, and carvacrol presented the best results, which were observed only during the finisher phase.

Similar results to those obtained by Hernández et al. (2004) for crude protein digestibility was reported in a grower broiler diet with the addition of the same commercial product containing plant extracts with capsaicin, cinnamaldehyde, and carvacrol (Rostagno et al., 2001). The improvement in amino acid digestibility may be related to capsaicin, the active principle of the plant extract used in the experiment. According to Platel \& Srinivasan (1996), capsaicin stimulates the action of proteases, particularly of trypsin and chemotrypsin, in laboratory animals.

\section{Plant extracts as performance enhancers}

As a function of plant extract properties and potential, several products are being tested as animal performance enhancers when added to feeds. The use of individual plant extracts to replace antibiotic performance enhancers was evaluated in studies conducted with broilers by Barreto (2007) and with newly-weaned piglets by Costa et al. (2007). Broiler performance was not statistically different when the control treatment (with no addition of performance enhancers) was compared to the treatments with antibiotics or with plant extracts. However, when clove and oregano extracts were included in piglet diets, they
Foundation and Perspectives of the Use of Plant Extracts as Performance Enhancers in Broilers

promoted similar performance as to that obtained with the use of antibiotics.

Although the active principles are responsible for the main effect on the animal, research studies show the presence of a synergistic effect among plant primary and secondary components. The secondary components would enhance the effects of the primary components (Kamel, 2000).

Some researchers believe that the administration of combinations of essential oils derived from different plants in animal diets promote better performance results (Langhout, 2000). The synergistic effect of essential oil components was observed in vitro in a mixture of eugenol and cinnamaldehyde. Differently from the results observed when these two compounds were individually added, their mixture was able to completely inhibit the growth of four bacteria for a period longer than 30 days (Moleyar \& Narasimham, 1992).

Studies carried out with broilers seem to confirm the in vitro findings. In a trial reviewed by Losa (2001), it was observed that the inclusion of a mixture of plant extracts reduced in $70 \%$ the number of broilers infected with Clostridium perfringens, improving their performance as compared to the control treatment with zinc bacitracin.

Other results report significant improvement of feed conversion ratio, weight gain, and carcass yield when broilers were fed a diet containing $48 \mathrm{ppm}$ of a combination of oregano, laurel, sage, fennel, Myrtus, and citrus as compared to birds fed a control diet or one containing 10 ppm avilamycin (Alçiçek et al., 2003). Studies carried out with plant extract mixtures containing capsaicin, cinnamaldehyde, and carvacrol (Rostagno et al., 2001) or 100 ppm oregano, cinnamon, thyme, and chili pepper essential oils (Zhang et al., 2005) in substitution of a antibiotic performance enhancer showed similar feed conversion ratio results as compared with the diet containing antibiotics.

Those studies show that plant extracts and their active principles may be used as an alternative to the use of antibiotic performance enhancers in animal nutrition. However, further studies on the effects of those compounds, their combinations, and dietary inclusion levels are needed to allow the animal industry to safely adopt them and to obtain the best cost/benefit in animal production.

\section{REFERENCES}

Agricultural Research Service. Duke's phytochemical and 


\section{Rizzo PV, Menten JFM, Racanicci AMC, Santarosa J}

Foundation and Perspectives of the Use of Plant Extracts as Performance Enhancers in Broilers ethnobotanical databases [cited 2006 abr]. Available from: http:// www.ars-grin.gov/duke/.

Alçiçek A, Bozkurt M, Çabuk M. The effect of an essential oil combination derived from selected herbs growing wild in Turkey on broiler performance. South African Journal of Animal Science 2003; 33(2):89-94

Associação Brasileira dos Produtores e Exportadores de Carne de Frango. Estatísticas [cited 2008 mar]. Available from: www.abef.com.br

Andrade AN. Mitos e verdades sobre o uso de antibióticos nas rações. Informativo do Conselho Regional de Medicina Veterinária do Estado do Rio de Janeiro 2007; (186) [cited 2007 feb]. Available from: http://www.crmvrj.com.br/new/jornal/artigos/ jornaljan2007.pdf.

Aveworld: a Revista do Avicultor Moderno. Promotores naturais de crescimento. Paulínia: Ed. Animalworld; 2005. 14p.

Barreto MSR. Uso de extratos vegetais como promotores do crescimento em frangos de corte [dissertação]. Piracicaba (SP): Universidade de São Paulo; 2007.

Botsoglou NA, Florou-Paneri P, Christaki E, Fletouris DJ, Spais AB. Effect of dietary oregano essential oil on performance of chickens and on iron-induced lipid oxidation of breast, tigh and abdominal fat tissues. British Poultry Science 2002a; 43:223-230.

Botsoglou NA, Christaki E, Fletouris DJ, Florou-Paneri P, Spais AB. The effect of dietary oregano essential oil on lipid oxidation in raw and cooked chicken during refrigerated storage. Meat Science 2002b; 62:259-265.

Botsoglou NA, Fletouris DJ, Florou-Paneri P, Christaki E, Spais AB. Inhibition of lipid oxidation in long-term frozen stored chicken meat by dietary oregano essential oil and $\alpha$-tocopheryl acetate supplementation. Food Research International 2003a; 36:207-213.

Botsoglou NA, Govaris A, Botsoglou EN, Grigoropoulou SH, Papageorgiou G. Antioxidant activity of dietary oregano essential oil and $\alpha$-tocopheryl acetate supplementation in long-term frozen stored turkey meat. Journal of Agricultural and Food Chemistry 2003b; 51:2930-2936.

Botsoglou NA, Florou-Paneri P, Christaki E, Giannenas I, Spais AB. Performance of rabbits and oxidative stability of muscle tissues as affected by dietary supplementation with oregano essential oil. Archives of Animal Nutrition 2004; 58(3):209-218.

Brugalll I. Alimentação alternativa: a utilização de fitoterápicos ou nutracêuticos como moduladores da imunidade e desempenho animal. Anais do Simpósio Sobre Manejo e Nutrição de Aves e Suínos; 2003; Campinas, São Paulo. Brasil. p.167-82.

Burt S. Essential oils: their antibacterial properties and potential applications in foods - a review. International Journal of Food Microbiology 2004; 94:223-253.

Carvalho JE. Fitoterapia. Anais da Conferência Apinco de Ciência e Tecnologia; 2005; Santos, São Paulo. Brasil. p.35-39.
Cechinel Filho V. Estratégias para a obtenção de compostos farmacologicamente ativos a partir de plantas medicinais. Conceitos sobre modificação estrutural para otimização da atividade. Química Nova 1998; 21:99-105.

Chao SC, Young DG, Oberg CJ. Screening for inhibitory activity of essential oils on selected bacteria, fungi and viruses. Journal of Essential Oil Research 2000; 12:639-649.

Coates ME, Fuller R, Harrison GF, Lev M, Suffolk SF. A comparison of the growth of chicks in the Gustafsson germ-free apparatus and in a convencional environment, with and without dietary supplements of penicilin. British Journal of Nutrition 1963; 17:141-151.

Costa LB, Tse MLP, Miyada, VS. Extratos vegetais como alternativas aos antimicrobianos promotores do crescimento de leitões recémdesmamados. Revista Brasileira de Zootecnia 2007; 36(3):589-595.

Cowan MM. Plants products as antimicrobial agents. Clinical Microbiology Reviews 1999; 14(4):564-582.

Didry N, Dubreuil L, Pinkas M. Activity of thymol, carvacrol, cinamaldehyde and eugenol on oral bacteria. Pharmaceutica Acta Helvetiae 1994; 69:25-28

Dorman HJD, Deans SG. Antimicrobial agents from plants: antibacterial activity of plant volatile oils. Journal of Applied Microbiology 2000; 88:308-316.

Elgayyar M, Draughon FA, Golden DA, Mount JR. Antimicrobial activity of essential oils from plants against selected pathogenic and saprophytic microorganisms. Journal of Food Protection 2001; 64(7):1019-1024.

García V, Catalá-Gregori P, Hernández F, Megías MD, Madrid J. Effect of formic acid and plant extracts on growth, nutrient digestibility, intestine mucosa morphology and meat yield of broilers. Journal Applied Poultry Research 2007; 16:555-562.

Hammer KA, Carson CF, Riley TV. Antimicrobial activity of essential oils and other plant extracts. Journal of Applied Microbiology 1999; 86:985-990

Helander IM, Alakomi HL, Latva-Kala K, Mattila-Sandholm T, Pol I, Smid EJ, Gorris LGM, Von Wright A. Characterization of the action of selected essential oil components on gram-negative bacteria. Journal of Agriculture Food and Chemistry 1998; 46:3590-3595.

Hernández F, Madrid J, Garcia V, Orengo J, Megias MD. Influence of two plant extracts on broilers performance, digestibility and digestive organ size. Poultry Science 2004; 83:169-174.

Hui YH. Oleoresins and essential oils. In: Hui YH, editor. Bailey's industrial oil and fat products. New York: Wiley-Interscience Publication; 1996; 6:145-153.

Huyghebaert G. Replacement of antibiotics in poultry. Proceedings of the Eastern Nutrition Conference; 2003; Quebec City. Canada. p.1-23.

Janssen AM, Scheffer JJC, Svendsen AB. Antimicrobial activity of essential oils: A 1976-1986 literature review. Aspects of the test methods. Planta Medica 1987; 53:395-398. 
Juven BJ, Kanner J, Schved F, Weisslowicz, H. Factors that interact with the antibacterial action of thyme essential oil and its active constituints. Journal of Applied Bacteriology 1994; 76:626-631.

Kamel C. A novel look at a classic approach of plant extracts [special number]. Feed Mix - The International Journal on Feed, Nutrition and Technology 2000; 9(6):19-24.

Kohlert C, Van Rensen I, Marz R, Schindler G, Graefe EU, Veit M. Bioavailability and pharmokinetics of natural volatile terpenes in animal and humans. Planta Medica 2000; 66:495-505.

Langhout $P$. New additives for broiler chickens [special number]. Feed Mix - The International Journal on Feed, Nutrition and Technology 2000; 9(6):24-27

Langhout P. Alternativas ao uso de quimioterápicos na dieta de aves: A visão da indústria e recentes avanços. Anais da Conferência Apinco de Ciência e Tecnologia; 2005; Santos, São Paulo. Brasil. p.21-33.

Lopez-Bote CJ, Gray JK, Goma EA, Flegal CJ. Effect of dietary administration of oil extracts from rasemary and sage on lipid oxidation in broiler meat. British Poultry Science 1998; 39:235240.

Losa R. The use of essential oils in animal nutrition. Cahiers Options Mediterraneennes 2001; 54:39-44.

Luna A, Lábaque MC, Zygadlo JA, Marín RH. Suplementación dietaria del pollo con components del aceite esencial de orégano: potencial antioxidante. Anais do 30th Congreso Argentino de Producción Animal; 2007; Santiago del Estero. Argentina. v.27, supp.1, NA 41.

Madsen HI, Bertelsen G, Skibsted LH. Antioxidative activity of spices and spice extracts. In: Risch SJ, HO SCT, editors. Spices, flavour chemistry and antioxidant properties. Washington: American Chemical Society; 1997. p.176-187.

Martins ER, Castro DM, Castellani DC, Dias JE. Plantas medicinais. Viçosa (MG): UFV; 2000

Mellor S. Alternatives to antibiotic. Pig Progress 2000; 16:18-21.

Menten JFM. Eficácia, efeito sinérgico e modo de ação de agentes antimicrobianos como promotores de crescimento de suínos [tese]. Piracicaba (SP): Universidade de São Paulo; 1995.

Mentem JFM. Aditivos alternativos na produção de aves: probióticos e prebióticos. Anais da Reunião Anual da Sociedade Brasileira de Zootecnia; 2001; Piracicaba, São Paulo. Brasil. p.141-157.

Mitsch P, Zitterl-Eglseer K, Kohler B, Gabler C, Losa R, Zimpernik I. The effect of two different blends of essential oil components on the proliferation of Clostridium perfringens in the intestines of broiler chickens. Poultry Science 2004; 83:669-675.

Moleyar V, Narasimham P. Antibacterial activity of essential components. International Journal of Food Microbiology 1992; 16:337-342.
National Research Council. The use of drugs in food animals Benefits and risks. Washington; 1999. 253p.

Oetting LL, Utiyama CE, Giani PA, Ruiz US, Miyada VS. Efeito de extratos vegetais e antimicrobianos sobre a digestibilidade aparente, o desempenho, a morfometria dos órgãos e a histologia intestinal de leitões recém-desmamados. Revista Brasileira de Zootecnia 2006; 35(4):1389-1397.

Peñalver P, Huerta B, Borge C, Astorga R, Romero R, Perea A. Antimicrobial activity of five essential oils against origin strains of the Enterobacteriaceae family. Acta Pathologica, Microbiologica et Immunologica Scandinavica 2005; 113:1-6.

Peres LEP. Metabolismo secundário [cited 2007 nov 10]. Available from: http://www.ciagri.usp.br/ lazaropp/FisioVegGradBio/ MetSec.pdf.

Peter KV. Handbook of herbs and spices. Cambridge: Woodhead Publishing; 2001.

Platel K, Srinivasan K. Influence of dietary spices or their active principles on digestive enzymes of small intestinal mucosa in rats. International Journal of Food Sciences and Nutrition 1996; 47:5559.

Racanicci AMC, Danielsen B, Menten JFM, Regitano-D'arce MAB, Skibsted LH. Antioxidant effect of dittany (Origanum dictamnus) in pre-cooked chicken meat balls during chill-storage in comparison to rosemary (Rosmarinus officinalis). European Food Research Technology 2004; 218:521-524.

Racanicci AMC, Danielsen B, Skibsted LH. Mate (Ilex paraguariensis) as a source of water extractable antioxidant for use in chicken meat. European Food Research Technology 2008; 227:255-260.

Rostagno HS, Albino LFT, Toledo RS, Carvalho DCC, Oliveira JE. Nutritional evaluation of the extract as an alternative to antibiotic growth promoters in broiler chickens diets. Viçosa: Degussa; 2001. $11 \mathrm{p}$.

Santurio JM, Santurio DF, Pozzatti P, Moraes C, Franchin PR, Alves $\mathrm{SH}$. Atividade antimicrobiana dos óleos essenciais de orégano, tomilho e canela frente a sorovares de Salmonella entérica de origem avícola. Ciência Rural 2007; 37(3):803-808.

Scheuermann GN, Cunha Junior A. Perspectivas para a utilização de produtos de origem vegetal como aditivos alternativos na alimentação de aves [cited 2006 oct 13]. Available http:// www.engormix.com/perspectivas_a_utilizacao_ produtos_p_artigos_16_AVG.htm.

Smith-Palmer A, Stewart J, Fyfe L. Antimicrobial properties of plant essential oils and essences against five import food-borne pathogens. Letters in Applied Microbiology 1998; 26:118-122.

Thomke S, Elwinger K. Review - Growth promotants in feeding pigs and poultry. I. Growth and feed efficiency responses to antibiotic growth promotants. Annales de Zootechnie 1998a; 47:85-97. Thomke S, Elwinger K. Review - Growth promotants in feeding pigs and poultry. II. Mode of action of antibiotic growth promotants. Annales de Zootechnie 1998b; 47:153-167. 
Trombetta D, Castelli F, Sarpietro MG, Venuti V, Cristani M, Daniele C, Saija A, Mazzanti G, Bisignano G. Mechanisms of antibacterial action of three monoterpenes. Antimicrobial Agents and Chemotherapy 2005; 49(6):2474-2478.

Valenzuela AB, Sanhueza J, Nieto S. Natural antioxidants in functional foods: from food safety to health benefits. Grasas y Aceites 2003; 54:295-303.

Visek WJ. The mode of growth promotion by antibiotics. Journal of Animal Science 1978; 46(5):1447-1469.

Zhang KY, Yan F, Keen CA, Waldroup PW. Evaluation of microencapsulated essential oils and organic acids in diets for broiler chickens. International Journal of Poultry Science 2005; 4(9):612619. 